\title{
Development of a video-microscopic method to compare the effect of a precipitation inhibitor
}

Christfort, J.F.; Plum, J.; Madsen, C.M.; Nielsen, Line Hagner; Müllertz, A.; Rades, T.

Publication date:

2016

Document Version

Peer reviewed version

Link back to DTU Orbit

Citation (APA):

Christfort, J. F., Plum, J., Madsen, C. M., Nielsen, L. H., Müllertz, A., \& Rades, T. (2016). Development of a video-microscopic method to compare the effect of a precipitation inhibitor. Poster session presented at 2016 AAPS Annual Meeting and Exposition, Denver, CO, United States.

\section{General rights}

Copyright and moral rights for the publications made accessible in the public portal are retained by the authors and/or other copyright owners and it is a condition of accessing publications that users recognise and abide by the legal requirements associated with these rights.

- Users may download and print one copy of any publication from the public portal for the purpose of private study or research.

- You may not further distribute the material or use it for any profit-making activity or commercial gain

- You may freely distribute the URL identifying the publication in the public portal 


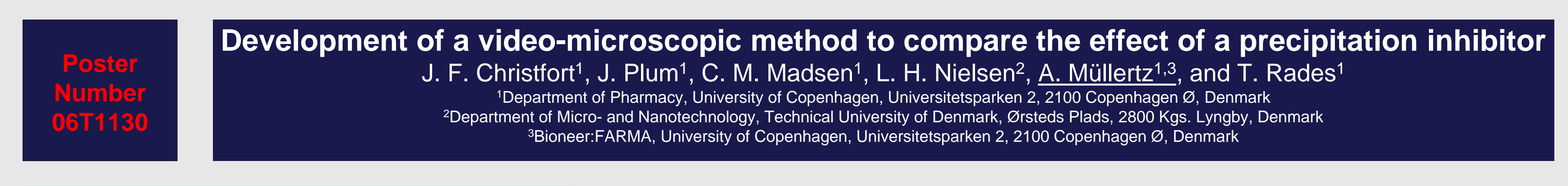

\section{PURPOSE}

The aim of this study was to develop a videomicroscopic method to evaluate the effect of a precipitation inhibitor $(\mathrm{PI})$ on supersaturated solutions of the poorly soluble drug tadalafil using a novel small the poorly
scale setup.

\section{CONCLUSION}

Tadalafil shows a prolonged induction time and a reduced growth rate in presence of HPMC.

- To significantly prolong the induction time and decrease particle growth, $0.01 \%$ w/v HPMC is needed.

- This is a promising tool for evaluating the effect of Pl's on induction time and crystallization rate of supersaturated systems of poorly soluble drugs.
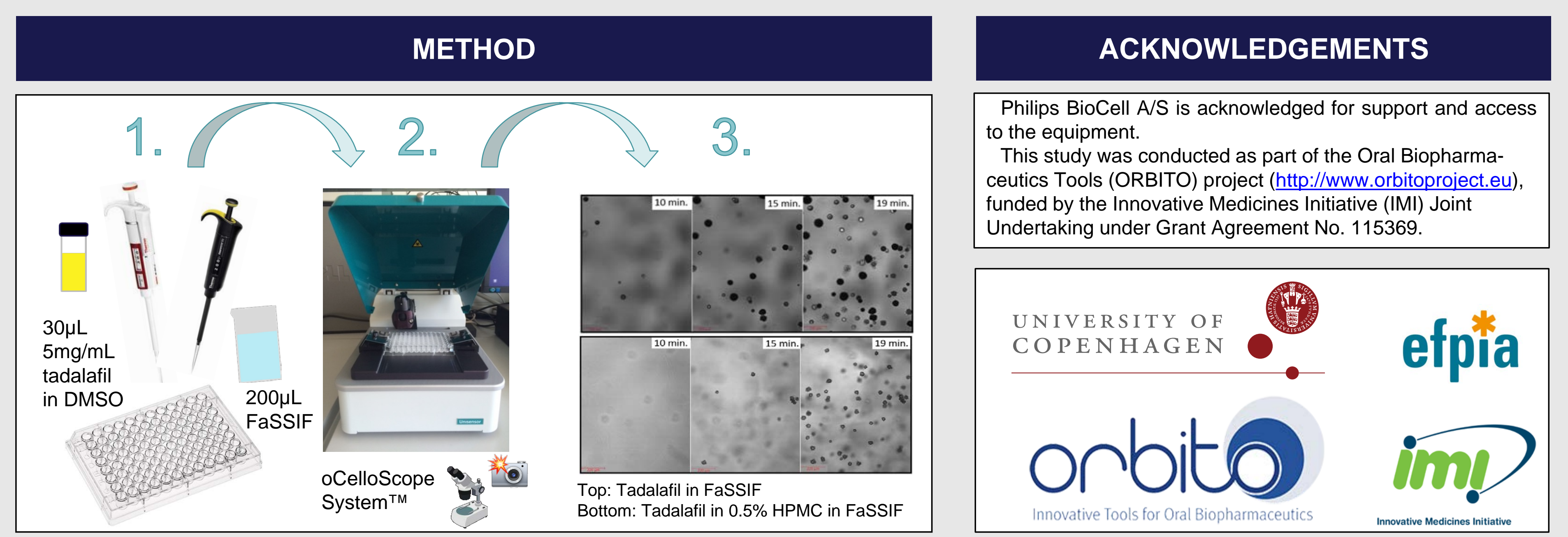

RESULTS
Proof of Concept

using the commercial software

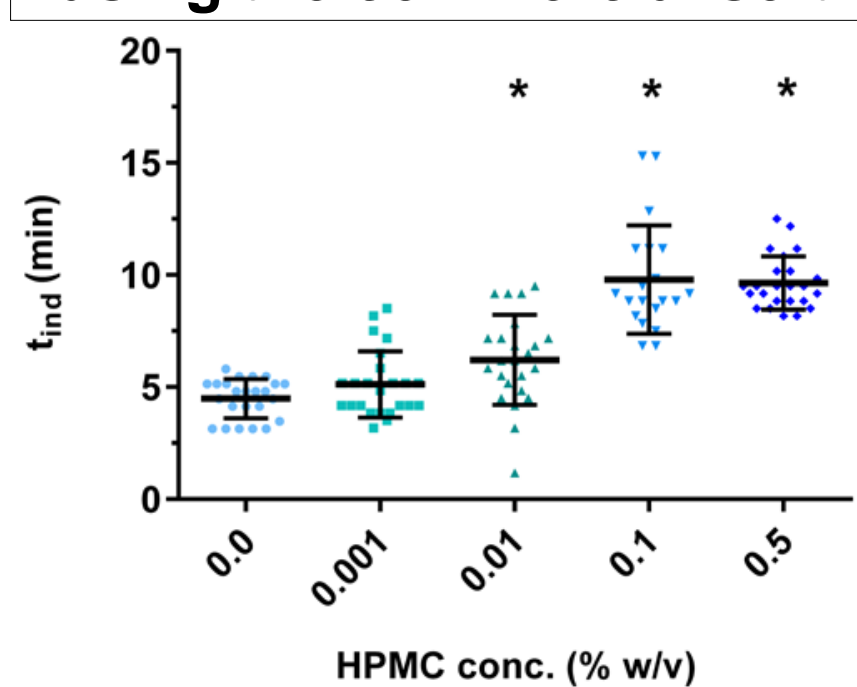

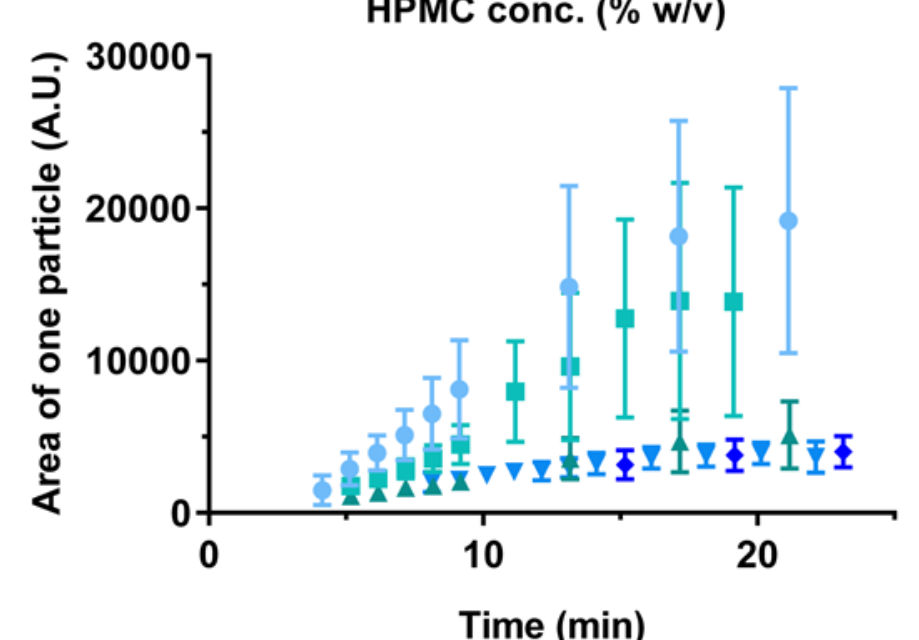

Time (min)

Top: Induction time for tadalafil in presence of HPMC Bottom: The area of one well defined particle per well as a function of time, with different HPMC conc., mean $\pm S D, n=3$ 24

\section{ACKNOWLEDGEMENTS}

\section{the equipment.}

This study was cr (itoproject.eu)

UNIVERSITYOF
COPENHAGEN

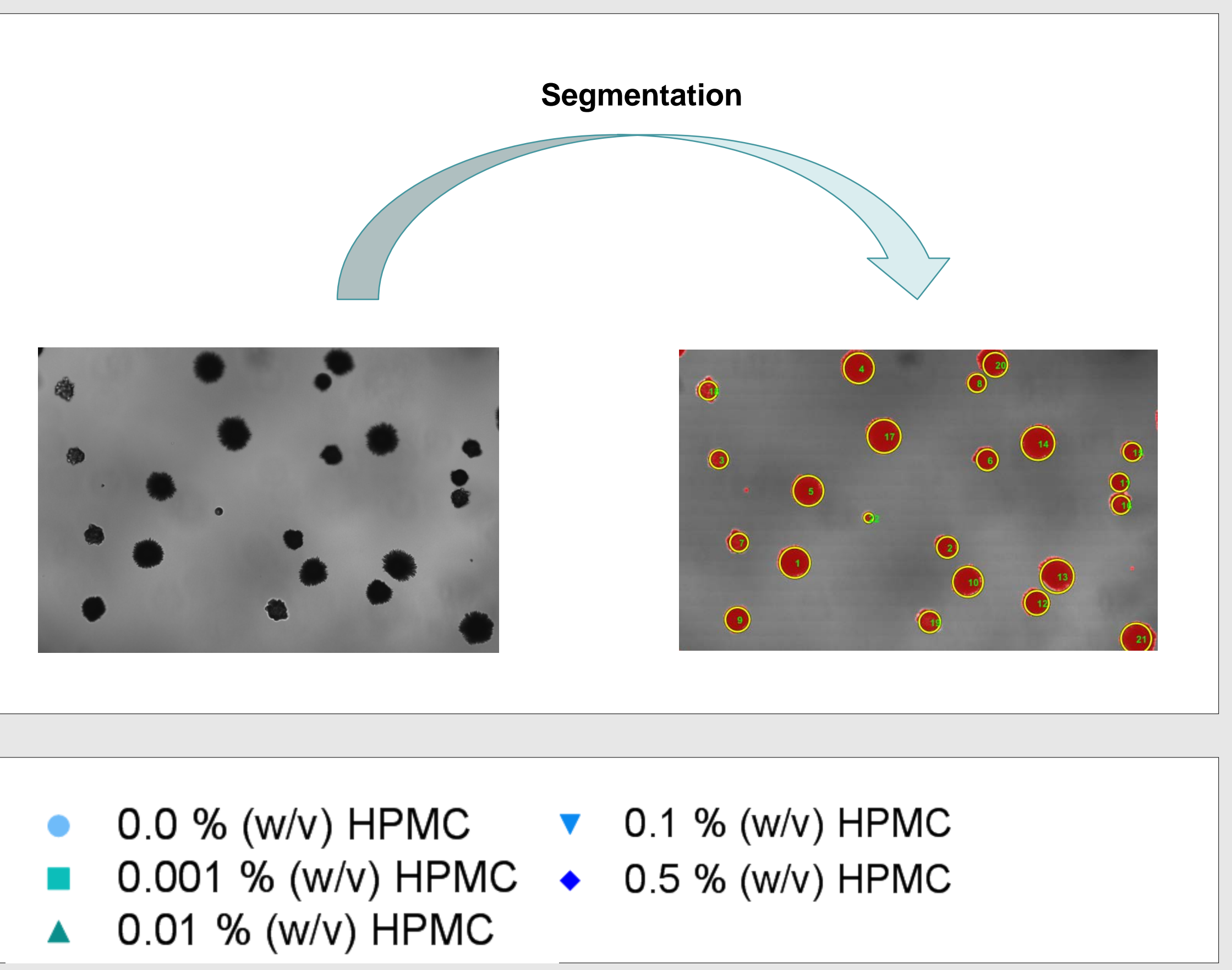

Improved Image analysis
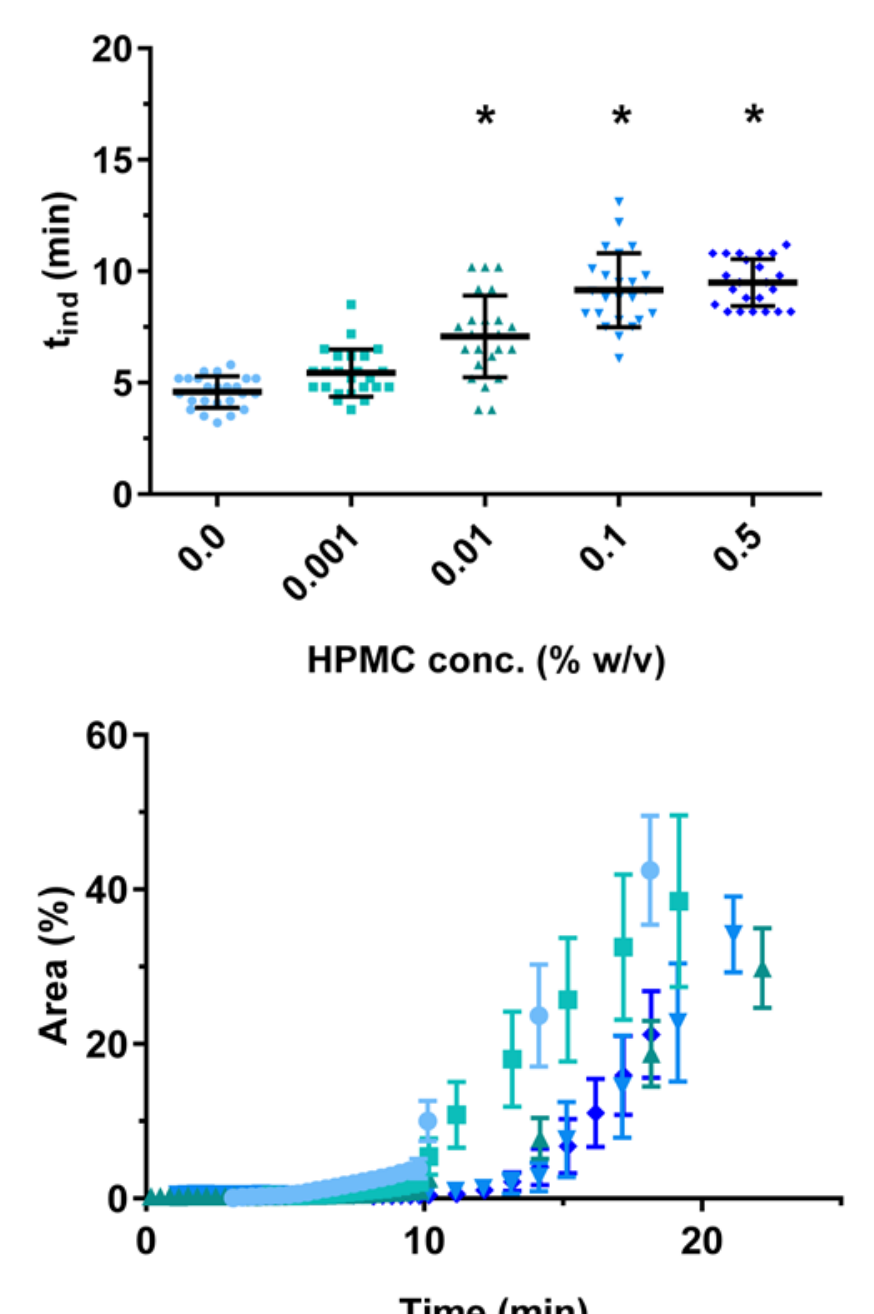

Top: Induction time for tadalafil in presence of HPMC Bottom: The total particle area as a function of time, with different HPMC conc., mean \pm SD, $n=24$ 